\title{
Activities of Medical Education Unit (MEU) in Medical Colleges of Bangladesh and some challenges faced
}

\author{
Brig Gen (Dr) Saidur Rahman ', Prof. Dr. Md. Humayun Kabir Talukder², Dr. Kazi Khairul Alam ${ }^{3}$
}

\begin{abstract}
Presence of MEU in medical colleges has been made as a measure of activities in National Quality Assurance guidelines for the improvement of medical education as well as faculty development. So, it is imperative to assess its activities in medical colleges for the expected outcomes which might facilitate administrators and policy makers for logical intervention where needed. Considering this matter, a descriptive type of cross sectional study was carried out to assess the status of activities of MEU in medical colleges of Bangladesh. Data was collected from 26 medical colleges of Bangladesh selected by purposive sampling method and 324 related available teachers by convenient sampling methods using a self-administered semistructured questionnaire. Total 26 MEUs coordinators or acting in charge as Key Informants were interviewed by using an interview schedule. A checklist was used for observation of existing MEU while visiting medical colleges for data collection. Principal/Vice Principal of medical colleges had responded to mailed letter as well as telephonic call and replied to have formal MEU at $20(91 \%)$ out of 22 government and at $81(98.2 \%)$ out of 83 non-government medical colleges. Around $87 \%$ faculty members usually attend the MEU activities which is conducted by MEU coordinators in $75 \%$ cases. CME program, pre and para clinical issue related activities occur in $70 \%$ cases. The experiences gained from MEU activities are utilized $88 \%$ in undergraduate class room, $59 \%$ in conducting CME activities and around $50 \%$ in other MEU activities. Staff related, Structural, faculty related, and administrative barriers have been identified by respondents and adequate fund and experienced staffs, motivation of faculty members and continued administrative monitoring can overcome those barriers (is it opinion? Of whom?). Key Informants opined MEU to take leading role in medical education development. Faculty members related to MEU should be adequately trained to impart interactive and effective education in both class room and bedside teaching. Policy level support, specific flow of fund, motivation and will of medical administrators and faculty members and proper monitoring by CME were found to be effective in establishing and functioning MEU in medical colleges. .
\end{abstract}

Keywords: MEU, MEU activities, faculty members, MEU barriers.

\section{Introduction}

A department of medical education is becoming an essential requirement for a medical school (Davis et al., 2009). The Medical Education Unit (MEU) is intended to be educational resource center for medical college teachers and students. The aim of the MEU, which are essentially a human resource consisting of a nucleus of faculty, is to bring about a continuing improvement in medical education, at the institutional and the national levels, in keeping with the changing health needs of the country(Talukder, 2014).

The MEU should have trained manpower on medical education, audio visual expert, computer operator and support staff. Physically they consist of office accommodation, a

\section{Deputy Commandant, Armed Forces Medical College Dhaka Cantonment, Dhaka. Dhaka \\ 2. Professor, Curriculum Development \& Evaluation Centre for Medical Education Mohakhali, Dhaka \\ 3. Assistant Professor, Medical Education Center for Medical Education, Dhaka.}

Address of correspondence:

Brig Gen (Dr) Md. Saidur Rahman

Deputy Commandant, Armed Forces Medical College

Dhaka Cantonment, Dhaka. Dhaka

Email: saidur.rahmam23@gmail.com meeting area, and storage space. They are equipped with computers, printer, multimedia projectors, OHP, screen, photocopier, scanner, video, digital camera etc. facilities and equipment for the production of educational media, as well as teaching equipment and learning materials which can be made available to teachers for use in their departments (Talukder, 2014).

The development of MEUs has been triggered by several factors such as curriculum reforms, need for faculty training, new methods for student selection, advances in medical informatics, the requirements from quality assurance and accreditation bodies, and education becoming a viable faculty career track (Al-Wardy, 2008).

In Bangladesh, Centre for Medical Education (CME) was established in 1983 for teachers training and reviewing and updating of different curricula. Since inception of CME it is trying its best to train the teachers on educational science, teaching methodology, assessment \& evaluation, instructional materials development, curriculum development and problem-based learning etc. But it is impossible for $\mathrm{CME}$ alone to provide training for the teachers of different postgraduate institutes, government and non-government medical college, dental college, IHTs, MATS, nursing institutes and nursing colleges etc. There should be provision to train the teachers of respective

Bangladesh Journal of Medical Education 2019;10(2):12-18. (C) 2019 Rahman S et al., publisher and licensee Association for Medical Education. This is an Open Access article which permits unrestricted non-commercial use, provided the original work is properly cited. 
institutes at own premises. Keeping this in mind initiatives were taken to establish medical education unit (MEU) \& medical skill center (MSC) in different medical colleges especially in old 8 medical colleges(Talukder, 2014).

This study outlines the necessity for establishing a medical education unit in medical colleges of Bangladesh. It reveals the possible function and scope of the activities of such units. It might help to for those institutions with an interest in establishing a new unit and also provide all medical teachers with suggestions as to what activities should usually take place in MEU to improve medical teachers and education as well.

\section{Materials and Methods}

A cross sectional descriptive study was conducted in 9 government and 17 non-government medical colleges of Bangladesh. Medical colleges were selected by purposive and 324 faculty members related to MEU in respective medical colleges were selected by convenient sampling methods and data were collected by a self-administered semistructured questionnaire. A mailed/faxed letter was sent to principal of all medical colleges and called the non-replying colleges over telephone asking presence of formal MEU. Total 29 Key Informants (KI) were interviewed in 26 visited medical colleges using a interview schedule. Out of them, 14 were professors, 9 associate professors and 6 assistant professors. A checklist was used for observation of existing MEU while visiting medical colleges for data collection.

Table 1 shows that out of total 105 (22 government and 83 non-government) medical colleges $20(91 \%)$ has formal MEU and the 2 MEU are yet to be opened out of 22 government medical colleges and, 81 (97.5\%) formal MEU are now existing out of 83 non-government medical colleges.

Table 1: Distribution of presence of formal MEU in medical colleges

\begin{tabular}{lccc}
\hline $\begin{array}{l}\text { Status of Medical } \\
\text { college }\end{array}$ & $\begin{array}{l}\text { Total number of } \\
\text { Medial College }\end{array}$ & $\begin{array}{c}\text { Presence of formal } \\
\text { MEU }\end{array}$ \\
\cline { 2 - 4 } & $\mathrm{N}$ & $\mathrm{n}$ & $\%$ \\
\hline $\begin{array}{l}\text { Government } \\
\text { medical college }\end{array}$ & 22 & 20 & 91 \\
$\begin{array}{l}\text { Non-government } \\
\text { Medical college }\end{array}$ & 83 & 81 & 97.5 \\
\hline Total & 105 & 101 & 96.2 \\
\hline
\end{tabular}

Figure 1 shows that among 324 respondents, maximum $27 \%$ respondents were Lecturers followed by 24\% Assistant Professors. Professor and Associate Professor were 19\% and $18 \%$ respectively.

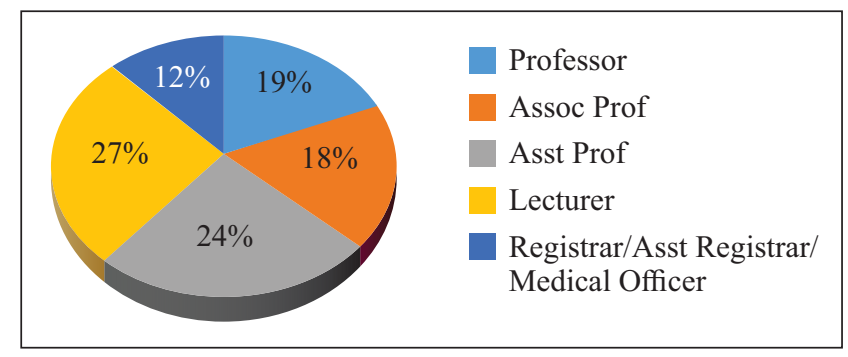

Figure 2 shows that more than $30 \%$ respondents witnessed that frequencies of MEU activities to occur on weekly and monthly basis. Only $5.9 \%$ respondents stated that MEU activities occur 2-3 times weekly.

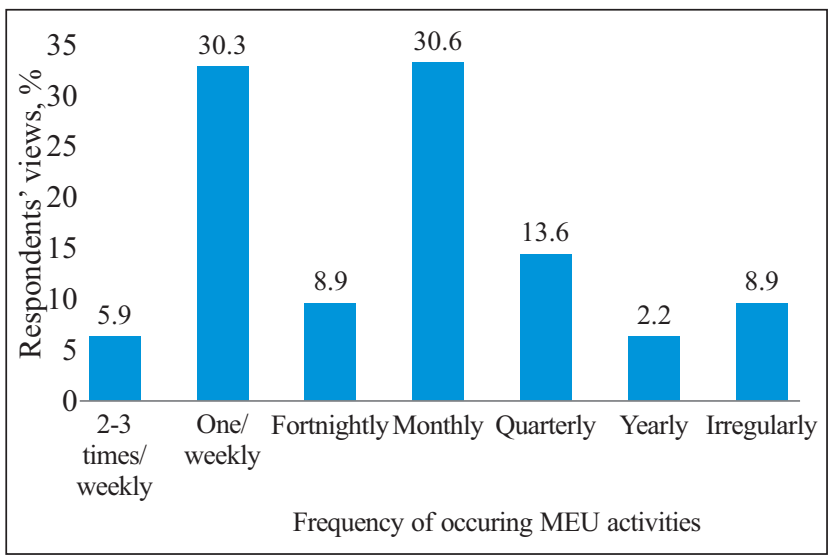

Figure 2: Distribution of respondents' views on frequency of pattern of occurring MEU activities. ( $\mathrm{n}=$ ?)

Table 2 shows $82.7 \%$ respondents stated that informal MEU activities are taking place irrespective of existence of formal MEU in medical colleges. Regarding the presence of MEU coordinator or a assigned responsible person, $88.3 \%$ respondents viewed in favor. Of which $87.7 \%$ are trained to conduct MEU activities. Around $50 \%$ MEU coordinators or assigned person for MEU are working part time. Regarding presence of required staffs, $65.9 \%$ respondents viewed in favor. $87.6 \%$ respondents faculty members said that they attended MEU activities in their respective medical colleges. 
Table 2: Respondents' views on frequency of informal MEU activities, attendance and staff status

\begin{tabular}{|c|c|c|c|}
\hline Views related to MEU activities & $\mathbf{n}$ & $\mathbf{n}$ & $\%$ \\
\hline Views on Informal MEU activities take place & 306 & & \\
\hline Yes & & 253 & 82.7 \\
\hline No & & 53 & 17.3 \\
\hline Any person assigned/MEU coordinator for MEU & 281 & 248 & 88.3 \\
\hline Yes & & 33 & 11.7 \\
\hline \multicolumn{4}{|l|}{ No } \\
\hline Views about presence of trained assigned person in conducting MEU activities & & 200 & 87.7 \\
\hline Assigned person full/part time & 232 & & \\
\hline Full time & & 95 & 40.9 \\
\hline Part time & & 137 & 59.1 \\
\hline Presence of required staffs for MEU & 296 & & \\
\hline Yes & & 195 & 65.9 \\
\hline No & & 101 & 34.1 \\
\hline MEU activities attended by respondents & 314 & & \\
\hline Yes & & 275 & 87.6 \\
\hline No & & 39 & 12.4 \\
\hline
\end{tabular}

Figure 3 shows different types of MEU activities are taking place institutionally. Highest $71.3 \%$ faculties stated of happening issues related to preclinical discipline and $70.5 \%$ viewed about CME program, $69.1 \%$ respondents said about happening issues related to clinical discipline and $58.5 \%$ stated about issues related to paraclinical discipline. $48.4 \%$ respondents also gave their assent in favor of faculty training on teaching methodology.

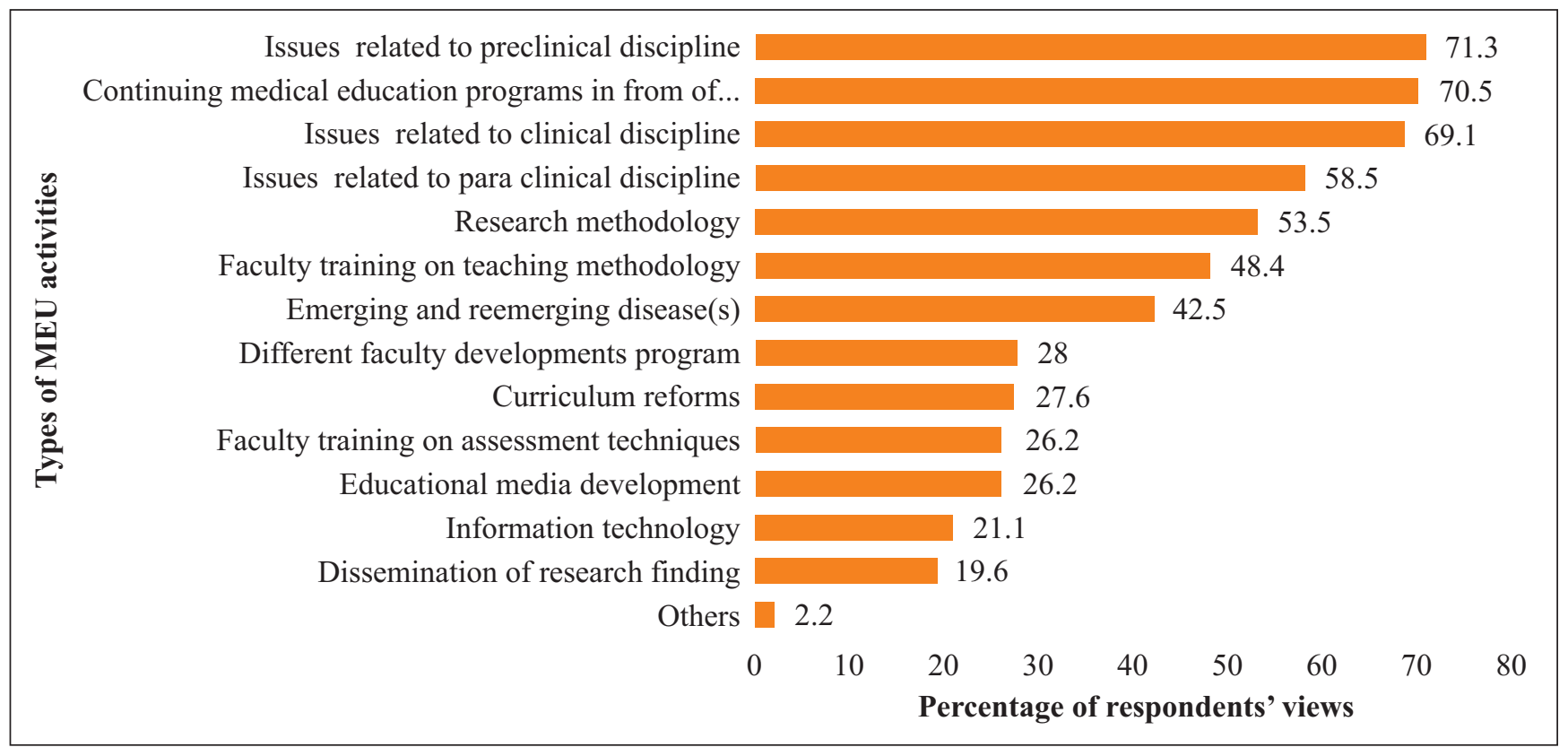

Bangladesh Journal of Medical Education 2019;10(2):12-18 
Table 3 shows that $84 \%$ respondents expressed that the person in charge of MEU or MEU/Academic coordinator usually conducts the MEU activities followed by the principal or Vice Principal who conducts the MEU activities in $61.1 \%$ cases. Assistant Register or Register conducts the MEU activities in $14.1 \%$ cases. Guest speakers conduct the MEU activities in $30.2 \%$ cases.

Table 3: Distribution of respondents' views on who conducts MEU activities

\begin{tabular}{lccc}
\hline $\begin{array}{l}\text { Person who conducts the MEU } \\
\text { activities }\end{array}$ & n & n & \% \\
\hline $\begin{array}{l}\text { Vice Principal/Principal } \\
\text { MEU Coordinator/Academic }\end{array}$ & 262 & 160 & 61.1 \\
$\begin{array}{l}\text { Coordinator } \\
\text { Departmental Head }\end{array}$ & 262 & 89 & 34 \\
$\begin{array}{l}\text { Senior teachers: Assistant } \\
\text { professor to Professor }\end{array}$ & 262 & 86 & 32.8 \\
$\begin{array}{l}\text { Juniors: Medical officer to } \\
\text { Assistant register/register }\end{array}$ & 262 & 37 & 14.1 \\
\begin{tabular}{l} 
Guest Speaker \\
\hline
\end{tabular} & 262 & 79 & 30.2 \\
\hline
\end{tabular}

Table 4 shows, all available teachers participate in MEU activities as supported by $88.1 \%$ respondents. MEU coordinators, departmental heads, College administrators and even undergraduate and postgraduate students (in respect of some government medical colleges) also participate in MEU activities in significant proportion as depicted in table below.

Table 4: Distribution respondents' views on who attends MEU activities

\begin{tabular}{lccc}
\hline Participants in MEU activitie & n & n & \% \\
\hline College administrators & 262 & 94 & 35.8 \\
MEU/Academic coordinators & 262 & 197 & 75.1 \\
Departmental heads & 262 & 182 & 69.4 \\
Available teachers & 262 & 231 & 88.1 \\
Available Undergraduate students & 262 & 121 & 46.2 \\
Available Postgraduate students & 262 & 74 & 28.2 \\
\hline
\end{tabular}

Figure 4 shows that a maximum $88 \%$ respondents viewed about utilization of gained knowledge in undergraduate class room, about 59.1\% respondents faculties said they utilize their gained experiences in conducting CME activities (eg, Seminar, Workshop etc), $54 \%$ stated about utilizing experiences in undergraduate assessment techniques application and $46.7 \%$ respondents viewed about utilization of gained experiences from MEU activities in clinical teaching session.

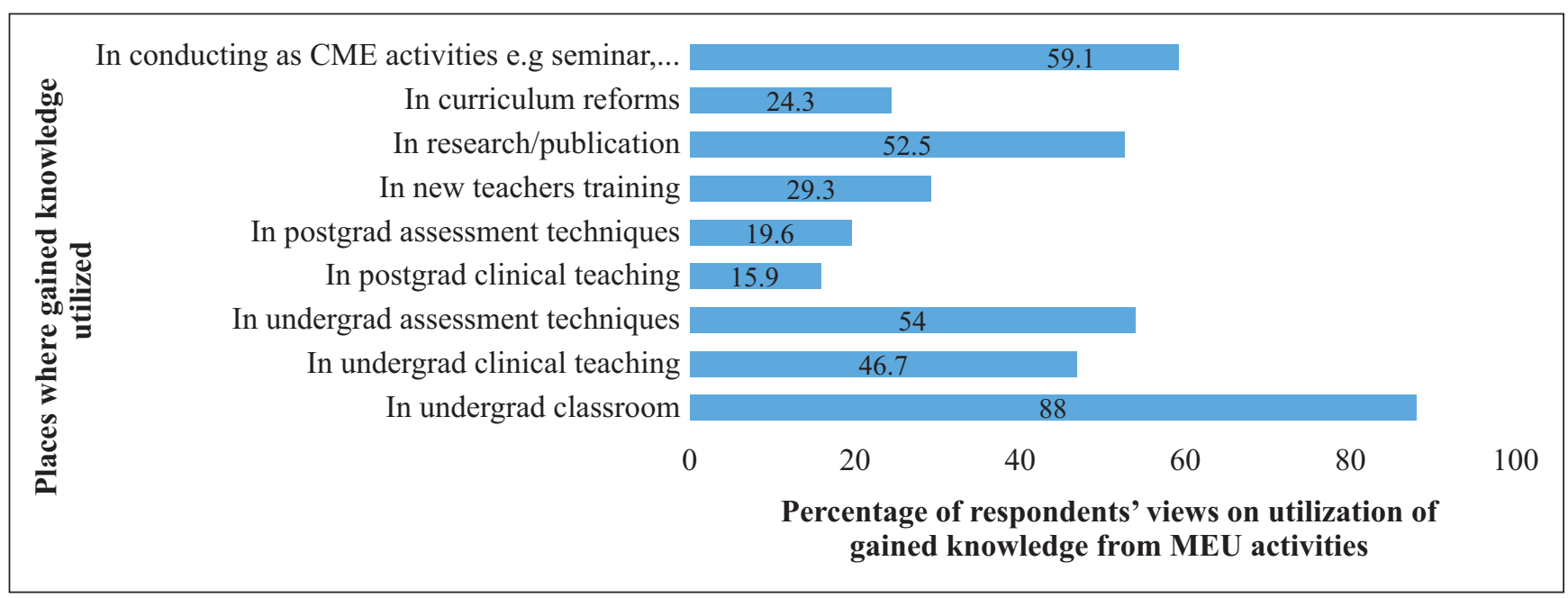

Figure 4: Distribution of respondents' views about areas on which knowledge gained from MEU activities is utilized (n=?)

Presently MEU activities cannot take place fully and properly due to facing some challenges like staff and faculty related barriers, structural barriers and administrative barriers. Table 5 highlights maximum $33.3 \%$ respondents viewed about existing MEU structure are not well maintained by the administration. In $38.7 \%$ cases, available space is not being spared for to executing MEU activities. In $28.7 \%$ cases, existing MEU remained busy for other routine educational activities. About $60.7 \%$ respondents opined lack of specific funding (both internal and external) as the prime administrative barriers. In $39.7 \%$ cases, administration faces difficulties not having trained manpower or expertise (who are qualified and trained in MEU) to be detailed in MEU governing committee. Around $12 \%$ respondents stated about disinterest, $29 \%$ viewed less prioritization by the administration and $13.5 \%$ respondents opined other way round that administration are not getting due cooperation from existing faculties

Bangladesh Journal of Medical Education 2019;10(2):12-18 
Table 5: Distribution of respondents' views on barrier for MEU activitiesnd Quarter 2014 Volume 7, Number 2, pp $165-170$

\begin{tabular}{|c|c|c|c|}
\hline Views on barriers for MEU activities & $\mathbf{n}$ & $\mathbf{n}$ & $\%$ \\
\hline Staff related barriers & 296 & & \\
\hline $\begin{array}{l}\text { Presence of required staff for MEU yes } \\
\text { or no }\end{array}$ & & 195 & 65.9 \\
\hline $\begin{array}{l}\text { Opinion regarding required number of } \\
\text { staff }\end{array}$ & & & $4.0 \pm 3.4$ \\
\hline $\begin{array}{l}\text { Structural barriers faced by respondents } \\
\text { faculty members }\end{array}$ & 261 & & \\
\hline No space available for MEU & & 42 & 16.1 \\
\hline Space available but not spared for MEU & & 101 & 38.7 \\
\hline $\begin{array}{l}\text { MEU available but busy with other } \\
\text { educational activities }\end{array}$ & & 75 & 28.7 \\
\hline $\begin{array}{l}\text { Existing MEU not well maintained by } \\
\text { administration }\end{array}$ & & 87 & 33.3 \\
\hline $\begin{array}{l}\text { Existing MEU not usable due to lack of } \\
\text { basic utility/facility }\end{array}$ & & 48 & 18.4 \\
\hline Others & & 23 & 8.8 \\
\hline $\begin{array}{l}\text { Administrative barriers faced by } \\
\text { respondent faculty members }\end{array}$ & 254 & & \\
\hline $\begin{array}{l}\text { MEU is not in the master plan of } \\
\text { medical college }\end{array}$ & & 117 & 46.4 \\
\hline No fund available to run MEU activities & & 153 & 60.7 \\
\hline $\begin{array}{l}\text { No trained manpower/expertise } \\
\text { available to detail as MEU } \\
\text { coordinator }\end{array}$ & & 100 & 39.7 \\
\hline Disinterest by the administration & & 31 & 12.3 \\
\hline Less prioritized by administration & & 73 & 29 \\
\hline Non- cooperation by the faculty & & 34 & 13.5 \\
\hline
\end{tabular}

Where several barriers have already been identified as shown in previous table, so respondents' views were taken regarding overcoming those barriers. Table 6 below shows that $66.3 \%$ respondents gave their views to construct or renovate a proper MEU venue from available fund and $40.1 \%$ faculty members opined to spare a suitable space in college building for the function of MEU. In overcoming faculty related barriers, $52.3 \%$ respondents viewed motivation of the faculty members by respective administration and $62.5 \%$ opined for motivating new junior teachers by the senior teachers. Highest $68.8 \%$ respondents stated that integrating MEU program with ongoing educational activities can best overcome the barriers for MEU activities to take place. Allocating required fund by the concerned authority has been opined by $54.9 \%$ respondents.
Table 6: Distribution of respondents' views on overcoming barriers related to MEU activities

\begin{tabular}{|c|c|c|c|}
\hline Overcoming barriers & $\mathbf{n}$ & $\mathbf{n}$ & $\%$ \\
\hline Structural & 294 & & \\
\hline $\begin{array}{l}\text { To construct/renovate a proper MEU } \\
\text { from available fund }\end{array}$ & & 195 & 66.3 \\
\hline To spare a suitable room for MEU & & 118 & 40.1 \\
\hline $\begin{array}{l}\text { To equip MEU with required facilities } \\
\text { and development }\end{array}$ & & 195 & 66.3 \\
\hline $\begin{array}{l}\text { Well and regular maintenance of MEU } \\
\text { by the administration }\end{array}$ & & 192 & 65.3 \\
\hline Staff and Faculties related & 285 & & \\
\hline Motivation by medical administrators & & 149 & 52.3 \\
\hline $\begin{array}{l}\text { Motivating junior teachers by seniors or } \\
\text { trained faculty }\end{array}$ & & 178 & 62.5 \\
\hline Cooperation from administration & & 139 & 48.8 \\
\hline $\begin{array}{l}\text { Integrating MEU program with ongoing } \\
\text { educational activities }\end{array}$ & & 196 & 68.8 \\
\hline Provisioning incentives/cash honourium & & 147 & 51.6 \\
\hline Administrative & 286 & & \\
\hline $\begin{array}{l}\text { Enforcing establishment of MEU by } \\
\text { higher authority }\end{array}$ & & 200 & 69.93 \\
\hline $\begin{array}{l}\text { Step from local authority to construct } \\
\text { MEU from available fund }\end{array}$ & & 140 & 48.95 \\
\hline $\begin{array}{l}\text { Allocating required fund by concerned } \\
\text { authority/sponsors }\end{array}$ & & 157 & 54.9 \\
\hline $\begin{array}{l}\text { Prioritizing the MEU activities by } \\
\text { administration }\end{array}$ & & 136 & 47.6 \\
\hline $\begin{array}{l}\text { Cooperation by the faculties for MEU } \\
\text { activities }\end{array}$ & & 129 & 45.1 \\
\hline $\begin{array}{l}\text { Monitoring the MEU activities by } \\
\text { administrators/coordinator }\end{array}$ & & 151 & 52.8 \\
\hline
\end{tabular}

\section{Discussion}

This cross-sectional study was carried out conveniently within available respondents of faculty members directly or indirectly involved with MEU in purposively selected 26 medical colleges. Primarily a total census of MEU was taken initially from received reply of a mailed letter to all medical colleges and later by telephone call in non-replied cases excluding those found during investigator's observations while physically visited for collecting data. It was found that $96.2 \%$ (101 out of 105) medical colleges are having MEU during data collection. Only 4 medical colleges, two government, and two non-government medical colleges do not have MEU.

In $82.7 \%$ cases, MEU activities mainly include pre-clinical, paraclinical and clinical issues conducted by MEU coordinator in most of the cases and attended by available faculties and students in $87 \%$ cases. The faculties usually utilize their gained experiences from MEU activities in 
undergraduate lecture hall, clinical bedside teaching and also in conducting CME activities in opportune moment. The study by Adkoli et al also revealed that utilization of gained experiences from MEU activities were done frequently in lecture, group discussion, demonstration etc (Adkoli and Sood, 2009)

Regarding MEU activities, Adkoli et al found in more than $60 \%$ cases in medical college in India, CME activities and clinical pathological conferences are held whereas this study reveals more than $70 \%$ of this sort of activities. But relatively less frequent were programmes on assessment techniques and educational media development are found similar in this study and the survey by Adkoli et al(Adkoli and Sood, 2009). This may be reasoned as the similar working conditions prevails in both countries. Further online survey on EU activities simultaneously in two countries might explore real picture of comparative MEU activities between two countries.

One distinct difference between this study and the study by Adkoli et al was Faculty Development Programmes (FDP) which revealed higher (60-90\%) in India and lower (26-28 $\%)$ in Bangladesh. This also warrants further explorative study on Faculty Development programme which might explore the true picture.

Regarding the MEU activities related to Faculty Development Programme (FDP) in different medical colleges in India, the study by Adkoli et al showed that faculty response about curriculum design is around 37\% (63 out of $\mathrm{n}=171$ ) whereas it is found below $30 \%$ in this study. This reflects curriculum design or reform issue at MEU in our medical colleges is little less thought-about matter that that of the study by Adkoli et al in India (Glocal Medical College Super Speciality Hospital \& Research Centre, 2016). The study on MEU in four medical schools in Sub Saharan countries (Kiguli-Malwadde et al., 2015) found that MEU departments in all four medical schools are having the facilities to support curriculum development, renewal and implementation although the motivators were different in four medical schools.

The respondents' views in favor of happening a common MEU activity is the research methodology in this study which is viewed around $54 \%$ whereas it is viewed only $28 \%$ in India study. This difference is also might be due to the difference in sample size of the respondents in two studies. The research in medical education was found not happening on ground in two schools out of surveyed four schools in Sub-Saharan countries(Kiguli-Malwadde et al., 2015).

Regarding the challenges or barriers behind MEU activities, Kiguli-Malwadde et al stated three barriers : Establishing and maintaining the legitimacy of the department within faculty and university leadership, securing and retaining appropriate staffs for MEU and sustaining the department in terms of funding (Kiguli-Malwadde et al., 2015). Adkoli at al also echoed some similar challenges like lack of infrastructure problem and funding, lack of incentive, recognition and scholarship; lack of support from top management, lack of faculty and support staff including full time, the constraints and pre-occupation with patient care, lack of evaluation, follow up and impact study (Adkoli and Sood, 2009).

The study by Adkoli et al and this study revealed the similar findings regarding the barrier of MEU like lack of infrastructure facilities, lack of funding, lack of faculty and support staffs, time constraints by the faculty members and lack of administrative support etc. Interviewing KII here in this study reveals lack of incentives, lack of recognition (CME score), scholarship etc which was responded by faculty group in the study by Adkoli et al(Adkoli and Sood, 2009)

Regarding overcoming the existing barriers for MEU activities, respondents of the present study suggested the need to strengthen the infrastructure, allocation of separate budget, facilities for learning resources and appointment of full time faculty and support staffs. Many respondents wanted participation in FDP to be a mandatory requirement for initial appointment and promotion. Some respondents suggested networking activities by forming regional and national associations which could hold annual meetings and bring out newsletters and journals in medical education. Some expressed the need to hold regular activities, extend activities from teacher training to include other areas such as leadership, managerial and communication skills, professionalism including ethics, and strengthening the evaluation component(Adkoli and Sood, 2009).

This study is based on the views of all level faculty members collected by a self-administered questionnaire and the views were analyzed on the presumptions that the response reflects the reality. As MEU is still in nascent state and yet to achieve its conceptual maturity, so the respondents' views may not reflect the realistic status. Studies are needed to address the issues at individual and institutional concerns regarding MEU/CME activities in medical education and outcome of such activities in improving medical education.

\section{Recommendations}

Based on this study findings following recommendations are made to activate MEU:

1) Political commitment with policy support should be there to institutionalize MEU in all medical colleges of Bangladesh. A consensus within all stakeholders is required to make it functional for overall improvement of medical education.

2) College administration should immediately form MEU governing body/committee preferably with medical education qualified personnel as focal point.

3) MEU body should make a yearly MEU activities calendar coordinating with the academic activities. Routine MEU activities should take place as per calendar and emerging health issues should be added as and when required. 
4) Regular CME activities like workshop, seminar should be integrated with MEU activities.

5) Regular Faculty Development Program (FDP), Teaching Methodology, Instructional Material Development Program, Research Methodology, curriculum reform and review session, multidiscipline clinical case presentation etc should be incorporated in MEU activities

6) MEU should be collaborated with the 'Journal Club' and important research activities should come out as journal publication

7) Administrators, MEU coordinators, senior faculties should take advocacy program to motivate and activate junior faculty members 8) Continued internal and external monitoring by college administrator and CME respectively should be strengthened.

\section{Conclusions}

Medical Education Unit is a tool for quality medical education. Imparting proper education is not easy as conceived. It has to go through proper teaching methodology, development of instructional material, developing learning material by students, curriculum review and reform, proper assessment techniques and medical research. MEU has to act as separate entity like other departments with full time trained MEU coordinator and supporting staffs. The unit should be teaching and learning friendly. All the faculties need to be creative and innovative by continued practice of medical education and professional development. College administrators has got the responsibility to ensure establishment and running of MEU in a suitable comfortable location in medical colleges. Medical teachers are expected to be the role model and students should follow them.

In this study the required MEU structure, staffs and activities related responses have been given by faculty members who were directly or indirectly involved with MEU. Some barriers or difficulties related information also have been identified by the response from faculty members and indepth interviewing MEU coordinators. Allocation of fund for MEU, motivation and cooperation of faculty, monitoring by $\mathrm{CME}$ and college administrators, provisioning of individual incentives are unearthed to overcome the barriers of MEU and to improve medical education.

\section{Acknowledgement}

Authors are much grateful to those faculty members who participated in this study. Moreover, authors like to extend their heartfelt thanks to the principals and MEU coordinators/in charge as the Key Informants and the faculty members as the respondents for administered questionnaire of selected 26 medical colleges of Bangladesh for their kind cooperation to conduct the study.

\section{Conflict of interest}

The authors declare no conflict of interest.

\section{References:}

1. Adkoli, B. \& Sood, R. 2009. Faculty development and medical education units in India: A Survey, The National Medical J of India, 22, 28-32.

2. Al-Wardy, N. M. 2008. Medical education units: History, functions, and organisation. Sultan Qaboos University Medical Journal, 8, 149.

3. Davis, M. H., Karunathilake, I. \& Harden, R. M. 2009. AMEE Education Guide no. 28: The development and role of departments of medical education. Medical teacher, 27, 665-675.

4. Glocal Medical College Super Speciality Hospital \& Research Centre. 18 Oct 2016 2016. RE: MEU office order.

5. Kiguli-Malwadde, E., Talib, Z. M., Wohltjen, H., Connors, S. C., Gandari, J., Banda, S. S., Maggio, L. A. \& Van Schalkwyk, S. C. 2015. Medical education departments: a study of four medical schools in SubSaharan Africa. BMC medical education, 15, 109.

6. Talukder, M. H. K. 2014. Establishing Medical Education Unit (MEU) and Medical Skill Centre (MSC) at Medical Institutes is the Demand of Present Time. Bangladesh Journal of Physiology and Pharmacology, 27, 28-30.

Bangladesh Journal of Medical Education 2019;10(2):12-18 